\title{
Febrile rhabdomyolysis in African migrants coming to Italy through the Mediterranean Sea: A report of four cases
}

\author{
Tony Sabatini, Antonella Begni, David Belli, Alida Filippini \\ Department of Internal Medicine \& Gastroenterology, Poliambulanza Hospital, Via L Bissolati, Brescia, Italy
}

Received: November 8, 2015

DOI: $10.5430 /$ crim.v3n1p36
Accepted: November 29, 2015 Online Published: December 15, 2015

URL: http://dx.doi.org/10.5430/crim.v3n1p36

\begin{abstract}
Introduction: In the last years many migrants, mostly from Africa and Middle East, are trying to reach Europe through the Mediterranean Sea. The crossing of the sea is usually associated to several problems, as overcrowding, promiscuous contacts with other people, physical and psychological distresses, malnutrition, dehydration and prolonged sunshine exposure.

Case presentation: We report the cases of four young people (three males and one female) African refugees presenting, after about 4 weeks from arrival in Europe, a febrile illness with high fever, severe prostration and very intense muscle aches with impossibility to stand and walk. Viral serology was not univocal. The patients recovered completely in almost a week.

Conclusions: We think that migrants of Refugees Centres should undergo to medical visits to check their clinical status and, in case of febrile illnesses, evaluated to understand the causes and the pathophysiology of these febrile diseases. It is also important to collect and register, from different European Refugee Centers through an International Organization, similar cases to prevent, in case of contagious diseases, the possible diffusion inside the Centres but also in the Community.
\end{abstract}

Key Words: Migrants, Rhabdomyolysis, Refugees, Mediterranean Sea

\section{INTRODUCTION}

In the last years many migrants, mostly from Subsaharian Africa but also from Middle East, are trying to reach Europe through the Mediterranean Sea. The crossing of the sea is usually associated to several problems, as overcrowding, promiscuous contacts with other people, squatting position for many hours or days, physical and psychological distresses, such as beating or injuries. Before landing, the migrants are subject for several days to malnutrition and dehydration, because of shortage of food and water associated to high temperatures and prolonged sunshine exposure. In some cases the shortage of water compels them to drink sea water. ${ }^{[1]}$ For the above mentioned factors these persons are exposed to several clinical problems, from transmissible contagious infective diseases to physical traumas, sun and/or heat strokes.

\section{Cases presentation}

We will report the cases of four black young people from Africa (Nigeria), three men, two 19-year-old and one 18-yearold, and a 19-year-old girl, admitted to our Internal Medicine Department, in the summer, 2015, coming from the same Refugee Center in Brescia (Italy); all had been there about one month after arrival in Italy (Lampedusa, Sicily) by boats.

\footnotetext{
*Correspondence: Tony Sabatini; Email: tony.sabatini@poliambulanza.it; Address: Department of Internal Medicine \& Gastroenterology, Poliambulanza Hospital, Via L Bissolati 57, 25124 Brescia, Italy.
} 
They did not show any medical or personal records. They were admitted to our Emergency Department for fever, in absence of shivering or shaking chills, severe prostration and very intense muscle aches with inability to stand and walk. Their names and past clinical histories were undefined; in particular they denied malaria, tuberculosis or other previous febrile illnesses. The chemistry showed, in all of them, normal creatinine level, elevated C Reactive Protein, mild thrombocytopenia (values between 65,000 to $110,000 / \mathrm{mm}^{3}$ ),

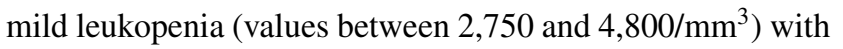
normal formula, severe rhabdomyolysis ${ }^{[2,3]}$ (values of total creatine-kinase of 36,790, 24,500, 18,540 and 11,916 U/L, respectively, see Table 1), brown urine in 3 of them (for myoglobinuria). One of them had also acute urinary retention and mental confusion; he had lumbar tip (negative for infection) and serological positivity for Parvovirus B 19 active infection (IgM 18.8 UA with positivity with values $>11.5$ UA and IgG 106.9 UA with positivity with values $>11.5$ UA); negative on the contrary the serology for EBV, CMV and Coxsackievirus. ${ }^{[4]}$ In two patient (the 18-year-old male and the 19-year-old girl), serological viral test evidenced IgM for Coxsackie B (IgG EIA $12.4 \mathrm{U} / \mathrm{ml}$ for the girl and $21.8 \mathrm{U} / \mathrm{ml}$ for the boy, with positivity if > $15 \mathrm{U} / \mathrm{ml}$; IgM resulted positive for both); negative all the serological tests for the four male patient. ${ }^{[5]}$ The clinical examination of the four patients did not pointed out cutaneous alterations, in particular hemorrhagic injuries, nor other abnormal signs.

We did only supportive treatment with hydration and analgesics, in particular acetaminophen and ketoprofen. Within a week clinical and laboratory values normalized, in particular fever disappeared and creatine phosphokinase (CPK) levels dropped to normal values; and the patients recovered almost completely. They were discharged but no more recruitable for informed consent and it is supposed they went to Northern Europe.

Table 1. Clinical and some laboratory parameters of the four patients

\begin{tabular}{lllll}
\hline & $\begin{array}{l}\text { CPK peak } \\
(\mathbf{U} / \mathbf{L})\end{array}$ & T max & $\begin{array}{l}\text { Platelet } \\
\mathbf{( m m}^{3} \mathbf{)}\end{array}$ & $\begin{array}{l}\text { Leukocytes } \\
\mathbf{( m m}^{\mathbf{3}} \mathbf{~}\end{array}$ \\
\hline Case 01, M19 & 36,790 & $40^{\circ} \mathrm{C}$ & 65,000 & 3,500 \\
Case 02, M19 & 24,500 & $39.5^{\circ} \mathrm{C}$ & 88,000 & 2,750 \\
Case 03, M18 & 11,916 & $38.5^{\circ} \mathrm{C}$ & 110,000 & 4,800 \\
Case 04, F19 & 18,540 & $39.5^{\circ} \mathrm{C}$ & 76,000 & 4,500 \\
\hline
\end{tabular}

\section{DisCUSSION}

We hypothesize that bland different viral infections (Parvovirus B19, Coxsackie B) may give severe similar clinical symptoms and signs with preeminent muscle involvement when predisposing condition (prolonged malnutrition, dehydration, promiscuity, prolonged squatting position) are present in these subjects. Also we wonder if these clinical pictures may be due to an unknown contagious viral infection.

\section{Conclusion}

We urge the qualified European Authorities to take care of the clinical problems of refugees, starting from supplying during the crossing adequate hydration and nutritional support. Finally it should be necessary to carry out health checks at arrival and in the Refugee Centers, especially to find potentially infective causes.

\section{Conflicts of InTERest Disclosure}

Being all of the patients refugees without documents, we did not have their identify o birth records; also they were not recruitable at the Refugee Centre, having they fled to Northern Europe.

\section{REFERENCES}

[1] Pasta L, Mesa Suero LA. Ingestion of sea water as cause of hypernatriemia and rhabdomyolysis in African migrants arriving in Lampedusa through the Strait of Sicily. Epidemiol Prev. 2012; 36(3-4): 141. PMid:22828224

[2] Nauss MD, Schmidt EL, Pancioli AM. Viral myositis leading to rhabdomyolysis: a case report and literature review. Am J Emerg Med. 2009; 27(3): 372.e5-372.e6. PMid:19328397 http://dx.doi.org $/ 10.1016 /$ j.ajem.2008.07.022
[3] Cervellin G, Comelli I, Lippi G. Rhabdomyolysis: historical background, clinical, diagnostic and therapeutic features. Clin Chem Lab Med. 2010; 48(6): 749-56. PMid:20298139 http://dx.doi.org /10.1515/CCLM. 2010.151

[4] Oliver ND, Millar A, Pendleton A. Case Report: A Case Report on Parvovirus B19 Associated Myositis. Case Reports in Rheumatology. 2012.

[5] Patel S, Mulyala R, Katta N. Unusual presentation of Coxsackie B Rhabdomyolysis: Case Report and Literature Review. Journal of Academic Hospital Medicine. 2014; 6(4). 